\title{
Relationship Of Knowledge Discuss Between Nurses And Leaders In The Effectiveness Of Implementing Nursing Care
}

\author{
Pratiwi Yuliansari, Christianto Nugroho \\ STIKES PamenangKediri, East Java \\ *tiwi173@gmail.com
}

\begin{abstract}
Nursing care is a complete service that is inherent to the patient. Nursing services become one of the main determinants of good or bad service in a hospital. The importance of maintaining good and professional nursing services is a shared responsibility between the leadership and the implementing nurse. The quality of nursing services can be created with good relations between leaders and nurses through knowledge discuss activities at every opportunity, both in supervision, hand over, joint discussions and other activities that involve the interests of a treatment room or a hospital. Knowledge discuss between the head of the room and the nurse can increase the nurse's knowledge of the latest science and technology that can be used as a reference in providing the best Nursing Care. In addition, through the support and supervision of the head of the nurse's room can improve skills and confidence in clinical decision making when dealing with patients problems. Patients who feel the maximum and professional's nursing services in a hospital will not hesitate to recommend the hospital to others so that it becomes their own benefit for the hospital. This study aim to examine the relationship of knowledge discuss between nurses and leaders in the effectiveness of implementing nursing care.

This type of research is descriptive correlational with cross sectional approach, with sampling by cluster sampling, and obtained a sample of 80 respondents. Research data were collected by questionnaire and observation form by researchers. The research data were then analyzed using a linear regression test with a significance level of $p<0.05$.

The results of the study found the significance value of knowledge discuss to effectiveness nursing care is $\mathrm{p}=0.002$ which can be interpreted that there is a relationship between knowledge discuss to effectiveness nursing care by supervision, with a percentage of the opportunity to influence by $51 \%$.

Nursing care is the main service in the hospital that must be maintained quality. One method in ensuring that quality is to ensure that nursing care providers are professional and competent staff, through the knowledge discuss activities of the nursing leader or head of the room can ensure and control it both during supervision and daily knowledge discuss.
\end{abstract}

Keyword : Nursing Care, Knowledge Discuss, Nursing Quality 


\section{STRADA Jurnal Ilmiah Kesehatan}

DOI: $10.30994 /$ sjik.v9i2.304

ISSN: 2252-3847 (print); 2614-350X (online)

Vol.9 No.2 November 2020 Page.392-398

\section{BACKGROUND}

Nursing services as the main actor of health services have an important role in carrying the good name of health institutions. Patients as customers of nursing services will feel satisfied if they receive good service, according to existing standards and quality, if customers are satisfied they will automatically be loyal to the agency (Yuliansari, Nursalam, \& Ahsan, 2017). Maintaining and ensuring optimal nursing services require commitment and effort from managers and leaders, one of the activities that can be carried out to control the performance of services is through nursing supervision. Supervision and guidance contained in supervision activities can maintain the implementation and success of a planned program. The success of supervision itself can be influenced by various factors, one of the internal factors is knowledge and motivation both from the leader or head of the room and between colleagues (Abdurrahman, Saleh A, 2019).

The nurse manager has a key role in facilitating clinical supervision through the provision of protected time and an appropriate environment for clinical superviseon to take place. To help nurses managers to achieve this, health care organizations should include clinical supervision in their corporate agenda and in the job descriptions of the nurses (Cruz, Carvalho, \& Sousa, 2012)

Through the supervision of the head of the room or nursing manager can ensure that nursing care provided by nurses has complied with existing operational standard procedures. The results of research conducted by previous researchers related to the implementation of actions and supervision, nurses who adhere to the daily schedule of activities as much as (38.5\%) and the results of nurse compliance after supervision of the head of the room obtained results (69.2\%) (Widarti, Suryani, \& Meikawati, 2014). Harmatiwi (2017) in her study found that the disobedience of supervisors on the protocol of supervision was quite high (60\%) and the majority of supervisors do with indirect supervision. Effective supervision is carried out fairly, with feedback and follow-up thereafter (Maulidiawati, Nursalam, \& Nihayati, 2017), in which implementation it is necessary to have communication and knowledge discuss. Knowledge discuss facilitates management in finding and solving problems that are happening through the knowledge of organizational members and sharing them throughout the organization (Lee, Kim, \& Kim, 2014).

Knowledge discuss has a positive effect on nurses in clinical decision making when faced with a problem (Kaartemo \& Känsäkoski, 2018). The diversity of nurses and multidisciplinary educational backgrounds in one room in the hospital should be ammunition for exchange of knowledge, these strategies can be more effective than online portals, e-learning modules, and written process documentation in increasing nurse competence. Human interaction is a powerful force for learning, engagement, and innovation (Zipperer, 2019).

Knowledge discuss in supervision provides an opportunity for nurses to express their opinions and knowledge, so that communication goes both ways and nurses do not feel intimidated by the supervision that aims to provide the best and quality nursing services. Nursing leaders or managers as supervisors are present as mentors and don't just tell them what to do.

\section{METHODS}

The research design used is descriptive correlational with cross sectional approach. The study population was all implementing nurses in the inpatient room at the hospital with a sample of 80 nurses taken by cluster random sampling. The research variables are 


\section{STRADA Jurnal Ilmiah Kesehatan}

DOI: $10.30994 /$ sjik.v9i2.304

ISSN: 2252-3847 (print); 2614-350X (online)

Vol.9 No.2 November 2020 Page.392-398

knowledge discuss and supervision as a method to make sure the effectiveness nursing care implementation. Data was collected through knowledge discuss questionnaires and operational standard supervision procedures which were assessed by observation sheets by researchers during June - July 2019. Data were then processed using simple linear regression with a significance value of $\mathrm{p}<0.005$.

\section{RESULT}

Tabulation data related to knowledge discuss variables can be seen in the following table:

Table 1 Tabulation of knowledge discuss variables in research Relationship Of Knowledge

Discuss Between Nurses And Leaders In The Effectiveness Of Implementing

Nursing Care

\begin{tabular}{ccccccc}
\hline \multirow{2}{*}{ Category } & \multicolumn{2}{c}{ Good } & \multicolumn{2}{c}{ Deficient } & \multicolumn{2}{c}{ Total } \\
\cline { 2 - 7 } & $\sum$ & $\%$ & $\sum$ & $\%$ & $\sum$ & $\%$ \\
\hline Knowledge discuss & 49 & $61 \%$ & 31 & $39 \%$ & 80 & $100 \%$ \\
\hline
\end{tabular}

The results of the recapitulation of research related to knowledge discuss can be seen in the table above, a number of 49 respondents $(61 \%)$ stated that knowledge discuss conducted in the room is in the good category.

Table 2 Tabulation of supervision variables in the research Relationship Of Knowledge

Discuss Between Nurses And Leaders In The Effectiveness Of Implementing

Nursing Care

\begin{tabular}{lcccccc}
\hline \multirow{2}{*}{ Supervision } & \multicolumn{2}{c}{ Good } & \multicolumn{2}{c}{ Deficient } & \multicolumn{2}{c}{ Total } \\
\cline { 2 - 7 } & $\sum$ & $\%$ & $\sum$ & $\%$ & $\sum$ & $\%$ \\
\hline 1. Pra supervision & 62 & $78 \%$ & 18 & $22 \%$ & 80 & $100 \%$ \\
\hline 2. Intra supervision & 54 & $68 \%$ & 26 & $32 \%$ & 80 & $100 \%$ \\
\hline 3. Pasca Supervision & 52 & $65 \%$ & 28 & $35 \%$ & 80 & $100 \%$ \\
\hline
\end{tabular}

There are three components in the implementation of nursing supervision, the preservation component is the highest component with a good predicate, namely 62 respondents $(78 \%)$, followed by the supervision component as many as 54 respondents $(68 \%)$ and after supervision there are 52 respondents $(65 \%)$.

Table 3 Relationship test results Relationship of Knowledge discuss To The Implementation Of Nursing Supervision In Improving The Quality Of Service

\begin{tabular}{ccccc}
\hline \multirow{2}{*}{ Relationship } & \multicolumn{3}{c}{ Supervision } \\
\cline { 2 - 5 } & $p$-value & $\beta$ & $\begin{array}{c}\text { Regresision } \\
\text { coefficient } \\
(\mathrm{B})\end{array}$ & $\begin{array}{c}\text { Opportunity } \\
\text { (R Square) (\%) }\end{array}$ \\
\hline Knowledge discuss & 0.002 & 0,263 & 0.437 & $51 \%$ \\
\hline
\end{tabular}

Table 3 shows the results of the hypothesis testing dependent variable Knowledge discuss of independent variables - supervision where there is a significant relationship between the two is evidenced by the significance value of $\mathrm{p}$ value $<0.05$ that is equal to $\mathrm{p}=$ 0.002. Coefficient $B$ is the coefficient of the direction of regression and states the average change in variable $\mathrm{Y}$ (Supervision) for each change in variable $\mathrm{X}$ (Knowledge discuss) per one unit. The change that occurs is an increase if the value of $\mathrm{B}$ is positive. It can be 


\section{STRADA Jurnal Ilmiah Kesehatan}

DOI: $10.30994 /$ sjik.v9i2.304

ISSN: 2252-3847 (print); 2614-350X (online)

Vol.9 No.2 November 2020 Page.392-398

interpreted that the value of supervision will increase by 0.437 per 1 point increase in knowledge discuss. The magnitude of the chance of variable $\mathrm{X}$ affecting variable $\mathrm{Y}$ is as much as $51 \%$. Whereas the $\beta$ value states that if there is no knowledge discuss, the Supervision value is 0.263 . It can be concluded that $\mathrm{H} 1$ is accepted or there is a relationship between knowledge discuss and nursing supervision.

\section{DISCUSSION}

Based on research data, knowledge discuss conducted in the room is in the good category. This shows that the culture of exchanging information has actually been formed and only requires a good management system so that the manner and content of the information in question constitutes good information and is useful for nursing care processes such as the latest science and technology.

Knowledge is valid and confirmed information owned by organizational heads in decision-making and actions to achieve success and competitive benefits that includes principles, ideas, skills, roles and trends that may help in decision-making (Tamta \& Rao, 2017). Knowledge discuss is a place for nurses to be able to provide advice, share knowledge, criticize, and provide justification in an objective and conducive situation so as to create a perspective that can be used as a consideration in clinical decision making to produce a quality service process for customers or patients.

Based on the research data, the highest component that received a good predicate at the research site in the supervision activities was the pre-supervision component. The presupervision activities themselves include the socialization of supervision activities, informed consent, and direction of procedures and assessment forms from the supervisor to the implementing nurse. Supervision is a control system that can be carried out on an activity or an existing system to maintain and improve quality. Nursing supervision is carried out by the leadership of the head of the room or the field of nursing to the implementing nurse through three components namely pre-supervision, intrasupervision, and post-supervision.

Supervision is the activity of directing, observing, guiding and evaluating the capabilities of individuals and organizations on an ongoing basis in completing tasks so as to produce better work (Widarti et al., 2014). Supervision activities can train the sensitivity of both the leadership capabilities of the head of the room and the personal ability of nurses, in supervision there is a culture of direct assessment based on confirmation (Struksnes et al., 2012). Clinical supervision is a framework for a professional reflection which involves development and learning support of the supervisee, or of the supervised nurse (Vaňková \& Bártlová, 2015)

The presupervised aspect received the highest good predicate compared to the other two aspects by respondents. In the pre-supervision activities the supervisor carries out instructions and explains the supervision procedures so that the fair principle can be fulfilled. Presupervised stage, the head of the room must state the assessment indicators used and what nursing care will be assessed, even before that the head of the room is recommended to make informed consent and inform the implementing nurse who will be supervised at least one day before the supervision (Abdurrahman, Saleh A, 2019). Sufficient healthcare practitioners with appropriate skills and competencies are needed to improve the health and well-being of populations (Sundler et al., 2019), to create this mutually influential relationship, a supportive system in nursing services is needed, one of which is through supervision based on knowledge discuss. 


\section{STRADA Jurnal Ilmiah Kesehatan}

DOI: $10.30994 /$ sjik.v9i2.304

ISSN: 2252-3847 (print); 2614-350X (online)

Vol.9 No.2 November 2020 Page.392-398

The head of the room as a supervisor unconsciously may have and often supervises the nurse in the room, but is not well documented and scheduled. Supervision is often limited to situational that does not follow the rules of supervision principles properly. The weakness of this kind of supervision makes it difficult for the head of the room to determine feed back and follow-up on the performance of each implementing nurse.

Good supervision by following systematic steps provides an opportunity for implementing nurses to raise questions, clarify, and even provide input. This point tries to be carried out in supervision based on knowledge discuss. Presupervised stage, the head of the room must state the assessment indicators used and what nursing care will be assessed, even before that the head of the room is recommended to make informed consent and inform the implementing nurse who will be supervised at least one day before the supervision.

The next stage is intra supervision, where during the implementation of nursing care procedures the supervisor actively accompanies the implementing nurse, conducts supervision, assessment and guidance. It is undeniable that nurses need support in their professional practice because their practice is much more complex and unpredictable than what is said in the nursing theory. Through clinical supervision, nurses can perform with expertise, improve and develop the quality of the care they provide to their clients, reduce stress and optimize their coping resources (Cruz, Carvalho, \& Sousa, 2014). Supervision carried out by the supervisor in this case is formal, involves a commitment full of responsibility by prioritizing the safety of both patients and nurses.

Based on the data obtained the supervision aspect with the highest less predicate is the post supervision aspect. Based on the observations of researchers during data collection, so far the head of the room as a supervisor has never personally supervised the nurses in the room, so that the head of the room has never had a special record related to the performance of each nurse and mapping training plans as well as the career and education levels of nurses in the room. Post-supervision aspects include feed back and follow-up from the head room supervision results on the nurse's performance, the intended performance includes knowledge, skills, and attitudes during the nursing care process. The head of the room is expected to be able to provide direction and have a planned improvement strategy in the future.

Post supervision includes how the supervisor submits the findings, conclusions, clarification process, feed back to follow up the supervision activities that have been carried out. It is central to the process of learning and to scope of the expansion of practice and should be seen as a means of encouraging self-assessment and analytical and reflective skills (Cruz et al., 2012). Implementation of supervision is not only limited to supervision of the work alone but is also quite capable of creating a conducive work environment, making a plan, identifying the needs and problems needed to provide further work support (Made \& Wati, 2018).

There is a significant relationship between knowledge discuss and nursing supervision, the magnitude of the chance of variable $\mathrm{X}$ affecting variable $\mathrm{Y}$ is as much as $51 \%$. The nurse who has knowledge will have good work behavior in accordance with what he knows, then assess and make decisions on something in accordance with the knowledge he has (Maramis et al., 2019).

The purpose of sharing information and knowledge in supervision activities is to provide clinical supervision in a non-judgmental, respectful and cooperative approach (Sheppard, Stacey, \& Aubeeluck, 2018). Especially if the head of the room supports and develops a culture of knowledge discuss through an organizational system that encourages 


\section{STRADA Jurnal Ilmiah Kesehatan}

DOI: $10.30994 /$ sjik.v9i2.304

ISSN: 2252-3847 (print); 2614-350X (online)

Vol.9 No.2 November 2020 Page.392-398

nurses to provide optimal care, there is greater participation and work effectiveness (Davies, Wong, \& Laschinger, 2011).

Through supervision based on knowledge discuss, leaders can help provide solutions to problems faced by staff departing from ideas and aspirations that arise from themselves, then leaders give better direction and guidance. This kind of thing will be considered wiser by staff in the midst of the development of science and technology today. Through the supervision of the head of the room and the nurse even between nurses can control and discuss with each other related to nursing care so that it can improve the quality of nursing services.

\section{CONCLUSIONS}

There is a very strong relationship between knowledge discuss with supervision with a percentage of the opportunity to influence by $51 \%$. Knowledge discuss-based supervision creates supervision situations as a medium and process of self-improvement and is not merely a judgment of individual mistakes. Both the nurse and the head of the room as supervisors can discuss with each other and transfer information held during the supervision process. Supervision that runs well is a form of good competency control, both in terms of systems, skills, and knowledge, so that the quality of nursing services can be created and improved.

\section{REFERENCES}

Abdurrahman, Saleh A, S. K. K. (2019). Jurnal Keperawatan Muhammadiyah, 2 (2). Jurnal Keperawatan Muhammadiyah, Edisi Khus, 46-50. Retrieved from http://journal.um-surabaya.ac.id/index.php/JKM\%0AStudi

Cruz, S., Carvalho, A. L., \& Sousa, P. (2014). Clinical Supervision: Priority Strategy to a Better Health. Procedia - Social and Behavioral Sciences, 112(Iceepsy 2013), 97101. https://doi.org/10.1016/j.sbspro.2014.01.1143

Cruz, S., Carvalho, L., \& Sousa, P. (2012). Clinical Supervision in Nursing: the (un)Known Phenomenon. Procedia - Social and Behavioral Sciences, 69(Iceepsy), 864-873. https://doi.org/10.1016/j.sbspro.2012.12.009

Davies, A., Wong, C. A., \& Laschinger, H. (2011). Nurses' participation in personal knowledge transfer: The role of leader-member exchange (LMX) and structural empowerment. Journal of Nursing Management, 19(5), 632-643. https://doi.org/10.1111/j.1365-2834.2011.01269.x

Kaartemo, V., \& Känsäkoski, H. (2018). Information and Knowledge Processes in Health Care Value Co-Creation and Co-Destruction. SAGE Open, 8(4). https://doi.org/10.1177/2158244018820482

Lee, E. J., Kim, H. S., \& Kim, H. Y. (2014). Relationships between core factors of knowledge management in hospital nursing organisations and outcomes of nursing performance. Journal of Clinical Nursing, 23(23-24), 3513-3524. https://doi.org/10.1111/jocn.12603

Made, N., \& Wati, N. (2018). Hubungan Supervisi Keperawatan Dengan Pelaksanaan Budaya Safety. Adi Husafa Nursing Journal, 4(2), 56-65.

Maramis, M. D., Doda, D. V, Ratag, B. T., Kesehatan, F., Universitas, M., \& Ratulangi, S. (2019). Hubungan Antara Pengawasan Atasan dan Pengetahuan dengan Tindakan Penggunaan Alat Pelindung Diri (APD) Pada Perawat di Rumah Sakit Umum Daerah (RSUD) Maria Walanda Maramis Kabupaten Minahasa Utara. Jurnal KESMAS, 8(5), $42-50$. 


\section{STRADA Jurnal Ilmiah Kesehatan}

DOI: $10.30994 /$ sjik.v9i2.304

Maulidiawati, I., Nursalam, N., \& Nihayati, H. E. (2017). Development of Supervision Model based Experiential Learning for the Implementation of Patient Safety Goals at Teaching Hospital in Surabaya. Jurnal Ners, 12(2), 158. https://doi.org/10.20473/jn.v12i2.4640

Sheppard, F., Stacey, G., \& Aubeeluck, A. (2018). The importance, impact and influence of group clinical supervision for graduate entry nursing students. Nurse Education in Practice, 28(March), 296-301. https://doi.org/10.1016/j.nepr.2017.11.015

Struksnes, S., Engelien, R. I., Bogsti, W. B., Moen, Ö. L., Nordhagen, S. S., Solvik, E., \& Arvidsson, B. (2012). Nurses' conceptions of how an alternative supervision model influences their competence in assessment of nursing students in clinical practice. Nurse Education in Practice, 12(2), 83-88. https://doi.org/10.1016/j.nepr.2011.07.009

Sundler, A. J., Blomberg, K., Bisholt, B., Eklund, A., Windahl, J., \& Larsson, M. (2019). Experiences of supervision during clinical education among specialised nursing students in Sweden: A cross-sectional study. Nurse Education Today, 79(May), 2024. https://doi.org/10.1016/j.nedt.2019.05.009

Tamta, V., \& Rao, M. K. (2017). Linking Emotional Intelligence to Knowledge Sharing Behaviour: Organizational Justice and Work Engagement as Mediators. Global Business Review, 18(6), 1580-1596. https://doi.org/10.1177/0972150917713087

Vaňková, M., \& Bártlová, S. (2015). Historical and foreign legacy for the supervision concept in the Czech nursing. Kontakt, 17(1), e32-e41. https://doi.org/10.1016/j.kontakt.2015.01.008

Widarti, D., Suryani, M., \& Meikawati, W. (2014). PENGARUH SUPERVISI KEPALA RUANG TERHADAP KEPATUHAN PERAWAT PADA JADWAL KEGIATAN HARIAN PERAWAT DI RUANG MAWAR DI RSUD UNGARAN. Jurnal Keperawatan Dan Kebidanan (JIKK). Retrieved from http://182.253.197.100/ejournal/index.php/ilmukeperawatan/article/view/215

Yuliansari, P., Nursalam, N., \& Ahsan, A. (2017). Service Quality is Related to Loyalty of Nursing Care Services Based on SERVQUAL Theory and the American Customer Satisfaction Index (ACSI). 3(Inc), 59-62. https://doi.org/10.2991/inc-17.2017.21

Zipperer, L. (2019). "Humanness"-A crucial component of knowledge sharing for patient safety. Journal of Patient Safety and Risk Management, 24(2), 55-56. https://doi.org/10.1177/2516043519826751 